Almir Alihodžić ${ }^{1}$

Novo Plakalović ${ }^{2}$
JEL: G2, G20, G21

DOI:10.5937/industrija44-10309

UDC: $336.77: 334.7(497.6)$

336.781 .5

Original Scientific Paper

\title{
Determinants of Credit Growth to Nonfinancial companies in B\&H
}

\author{
Article history: \\ Received: 20 February 2016 \\ Sent for revision: 18 Mart 2016 \\ Received in revised form: 13 May 2016 \\ Accepted: 16 May 2016 \\ Available online: 11 July 2016
}

Abstract: Non-financial sector in B\&H and the companies due to lack of its own funds for sustainable growth rely on financing its operations through bank loans. The dominant share of lending to banks in $\mathrm{B} \& \mathrm{H}$ is directed to the household sector while on the other hand the approval of bank loans to enterprises is on a smaller scale. Corporate sector due to underdeveloped capital markets is not able to borrow through the issuance of equity and debt securities. The main objective of this study is to determine which independent variables in the regression models have an impact on the amount of approved loans granted by banks to non-financial sector, i.e. companies. The loans growth rate will be observed as a dependent variable, and the growth rate of non-performing loans, the growth rate of operating costs, real GDP growth, consumer price index, deposit growth rate, deposit interest rate, interest rate (EURIBOR), and interest rate (LIBOR) will be used as independent variables.

Key words: growth of bank loans, bank loans to nonfinancial companies, factors of bank loans growth, macroeconomic factors of bank loan growth

\section{Determinante kreditnog rasta nefinansijskog sektora u Bosni i Hercegovini}

Apstrakt: Nefinansijski sector u Bosni i Hercegovini i preduzeća zbog nedostatka sopstvenih sredstava za održivi rast se oslanjaju na finansiranje svog poslovanja putem bankarskih kredita. Dominantno učešće u pogledu kreditiranja banaka u BiH je usmereno prema sektoru stanovništva, dok je sa

\footnotetext{
${ }^{1}$ University of Zenica, Faculty of Economics, Bosnia and Herzegovina, almir.dr2@gmail.com

${ }^{2}$ University of East Sarajevo, Faculty of Economics, Republic of Srpska
} 
Alihodžić A., Plakalović N.: Determinants of Credit Growth to Nonfinancial companies..

druge strane odobravanje kredita preduzećima izraženo u manjem obimu. Korporativni sector nije u mogućnosti da pozajmljuje novčana sredstva putem izdavanja vlasničkih i dužničkih hartija od vrednosti zbog nerazvijenosti tržišta kapitala. Glavni cilj ovog istraživanja je da se utvrdi koje nezavisne varijable u regresivnom modelu imaju uticaj na visinu odobrenih kredita banaka prema nefinansijskom sektoru, tj. preduzećima. Stopa rasta kredita će se posmatrati kao zavisna varijabla, dok stopa rasta nekvalitetnih kredita, stopa rasta operativnih troškova, stopa rasta realnog BDP-a, indeks potrošačkih cena, stopa rasta depozita, kamatne stope na depozite, kamatna stopa EURIBOR, $i$ kamatna stopa LIBOR će se posmatrati kao nezavisne varijable.

Ključne reči: stopa rasta kredita, bankarski krediti nefinansijskim preduzećima, faktori rasta kredita, makroekonomski faktori rasta bankarskih kredita.

\section{Introduction}

In this paper, we try to determine the importance of certain variables on the growth of bank lending in $\mathrm{B} \& \mathrm{H}$. Credit expansion in $\mathrm{B} \& \mathrm{H}$ was very strong in the period up to the moment spill over of the global economic crisis and the region of Southeast Europe and B\&H. Excessive credit expansion has been developing on the basis of a strong inflow of foreign capital in the country that is largely touched by banking flows of financial resources. All this resulted in the emergence of macroeconomic imbalances but at the same time have a positive effect on consumption and economic growth. In this research, we focused on the period after the spillover of the crisis and stagnation of economic growth in the country. We have tried to identify and quantify the impact of certain factors on the level of credit expansion in B\&H in the last 9 years.

This research is designed and presented in four sections. The first section refers to the introductory considerations, the second part present the relevant literature, the third part describes the theoretical assumption and perceptions the regression model and gives a definition of significant independent variables that affect the loans growth rate alone whereas the last part of the paper discusses the results of research, based on the application of the regression model. This research will test the significance of observed financial variables in the model, where the null hypothesis is the reason why the independent variables do not significantly affect the dependent ones. In this context, it is stated that the observed independent variables have the greatest impact on the growth or decline rate of loans growth rate for the banking sector in B\&H. Finally, there are few interesting concluding remarks. 
Alihodžić A., Plakalović N.: Determinants of Credit Growth to Nonfinancial companies..

\section{Actual changes in magnitude of bank loans and deposits in B\&H}

The banking sector is still a dominating sector in the financial system while the remaining part of the financial system is rather underdeveloped. B\&H banking sector recorded a slight increase of the balance sheet amount, therefore the share of banks assets in the total assets of financial intermediaries increased by 20 basis points. The absence of large domestic institutional investors, lack of willingness to invest in the securities by households and the corporate sector are still the limiting factors for the growth of domestic investment funds. The domestic capital market, due to their segmentation, is not sufficiently attractive to foreign investors. The most active segment of the capital market is still trading in domestic debt securities (Central bank of Bosnia and Herzegovina, Financial Stability Report, 2014., p 41). Bosnian financial market is the bank-centred, which means that bank loans are the primary source of financing companies.

Figure 1. Number of banks in the Bosnia and Herzegovina for the period: $2007-$ Q2 2015

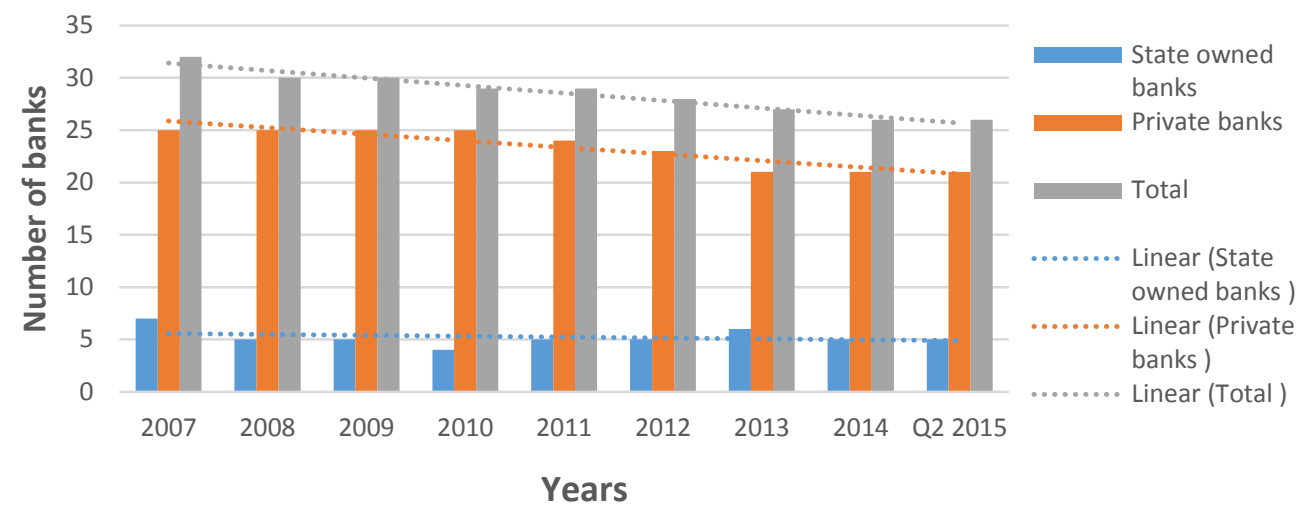

Source: The author's research based on a data available on www.fba.ba and www.abrs.ba

Figure 1 shows the movement of the number of banks on the market for a period from 2007 until the end of the second quarter of 2015. In 2007 in B\&H, there were 7 state-owned banks, whereas in the second quarter of 2015 there were only 5 state-owned banks. On the other hand, in 2007 there were 25 private banks, while in Q2 2015 there were 21 such banks. For partial reduction in the number of domestic as well as foreign banks, affected by the global economic crisis, there was a reduction of the scope of business activities, and consolidation legislation. 
Alihodžić A., Plakalović N.: Determinants of Credit Growth to Nonfinancial companies..

The stagnating lending activity and a high level of credit risk were the main features of the corporate sector in B\&H in recent year. A low demand of corporate sector for loans was a consequence of several factors, such as the long-lasting stagnation of economic activities in the country, weak domestic demand, low level of personal spending, absence of a significant investment cycle, and the overall macroeconomic and political circumstances in the country. (Central bank of Bosnia and Herzegovina, Financial Stability Report, 2014, p 35).

Figure 2. Trend in loans to nonfinancial public enterprises, private enterprises and cooperatives and loans to households for the period: Q1 2007-Q2 2015

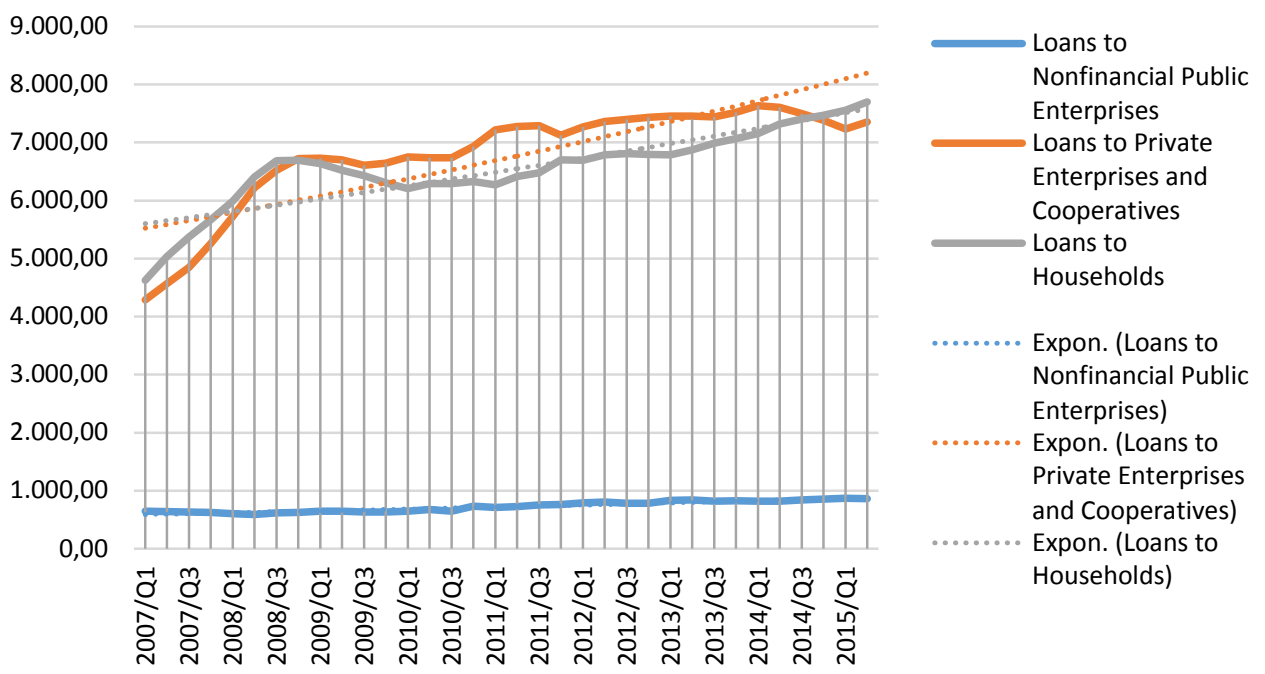

Source: The authors' research based on date available on www.cbbih.ba

Annual growth rates of loans were between 2 and 4\% during 2014 year. Longterm loans had slightly higher growth rates compared to short-term loans. Therefore, annual growth rate of long-term loans to private non-financial companies amounted up to modest $2 \%$ during the year. The main reason for the decrease in lending activity are the strict conditions for extending new loans contributed a lot to weak lending activities to non-financial companies. Slightly higher growth rates of loans were recorded with households. Annual rate of the growth of the loans to households was on the average around $5.7 \%$, which is significantly higher compared to the growth rates of the loans to private companies (Annual report of the Central Bank of B\&H, p 23). 
Alihodžić A., Plakalović N.: Determinants of Credit Growth to Nonfinancial companies..

Figure 3. Trend in deposits to nonfinancial public enterprises, private enterprises and cooperatives and loans to households for the period: Q1 2007 - Q2 2015
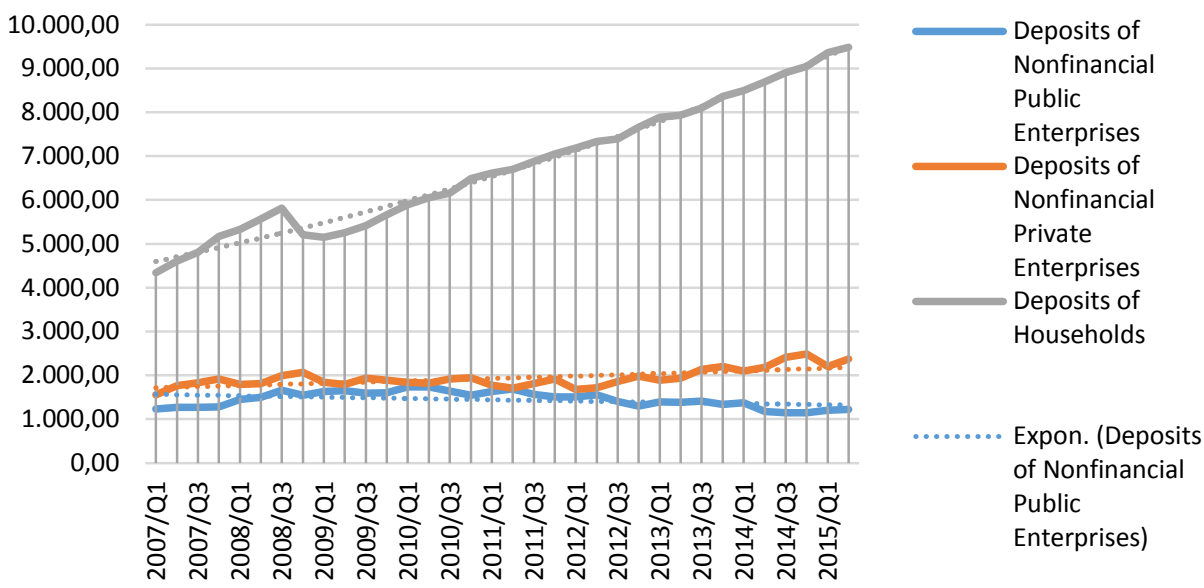

Source: The authors' research based on date available on www.cbbih.ba

From the above graphic it can be noted that the largest average quarterly growth of deposits for the period Q1 2007 - Q2 2015 was recorded to be in a sector of the households, i.e. $6.24 \%$. The second place at the average quarterly growth of deposits belongs to the sector of the nonfinancial private enterprises (4.37\%). On the other hand, the sector of nonfinancial public enterprises was recorded of the negative growth rate of $0.51 \%$. The growth of household deposits cannot be interpreted as the indicator of a better standard of living, but it is mainly a consequence of the uncertainty in respect of the future economic circumstances in the country, and the advantage is given to saving instead of spending. At the same time, the growth of the deposits of households is the indicator of trust in the banking sector and the decision of households to choose a safer kind of saving compared to investments in securities, despite the continued downward trend of deposit interest rates (Central bank of Bosnia and Herzegovina, Financial Stability Report, 2014 p 33).

\section{Brief Literature Review}

The main objective of macroeconomic tests that increasingly converge with the financial crisis is to establish the structural vulnerabilities in financial systems. The ultimate goal is to score their resilience to shocks and especially 
Alihodžić A., Plakalović N.: Determinants of Credit Growth to Nonfinancial companies..

the vulnerability of banks due to losses. Banks credit risk increases with the deterioration of the situation and the increase in interest payments as a result of which can be found in many models of credit risk (IMF, 2006).

Some research suggests (Espinoza R. Prasad A. 2010) that in the period 1995-2008 on a sample of 80 banks from the countries of the Gulf Cooperation Council - GCC, the non-performing ratio worsened as economic growth slows and interest rates and risk aversion rises. The applied model shows that the cumulative effects of macroeconomic shocks over a three-year horizon large (Espinoza R. Prasad 2010, p 1). Specific factors related to individual banks related to underwriting and efficiency are also related to future NPLs. Controls on banks efficiency and expansion of the previous balance (the previous dynamic growth in loans) and are important for the growth of NPLs. Return effects of NPLs (bank losses) on slowing growth are also present.

In contrast to research Levine, Loayza, Beck (2000), Favara shows that the relationship between financial development (the level of liquid liabilities of a banking system and amount of credit issued to the private sector by banks and other financial institutions) and economic growth is weak. This is about the observation of these relationships in the long term. There is a significant impact of credit growth in the real GDP growth and the magnitude of transmission channels through which loans on real activity depend on the specific type of loan (Garcia - M. Escribano, F. Han, 2015) so that the impact of the credit shock in terms of lending corporations influence mainly through investments, and credit shocks to consumer credit should go together with private consumption. Thus, the impact of the credit expansion is seen in this study by analysing the composition of credit portfolio (corporate, consumer and housing credit) on economic growth in emerging market economies. At the same time observe and influence expansion and composition of credit played in diving real GDP growth in the past.

Countries in which there was a good climate for foreign capital inflows are usually alive and in sharp credit expansions. Magud N.Reinhart C, Vesperon E. (2012) analysed the impact of exchange rate flexibility on credit markets during periods of large capital inflows. Bank credit grows more rapidly and its composition tilts to foreign currency in economies with less flexible exchange rate regimes. That is exactly the case in Bosnia and Herzegovina where the regime currency index was a strong factor of influence on the inflow of foreign capital and, as a result, there was a huge credit expansion of loans into domestic sectors in the past. Rapid credit growth has been driven by successful macroeconomic stabilization, robust growth, and capital inflow in transition economies. Financial deepening is both expected and welcome, the recent expansion (to the crisis) appears to have been excessive, as 
Alihodžić A., Plakalović N.: Determinants of Credit Growth to Nonfinancial companies..

evidenced by widening current account deficits and prudential concerns in some countries. (Duenwald C.Gueorguiev N. 2005).

Very rapid credit expansion over several years is a subject to a significant macroeconomic imbalance, largely fuelled by this rapid credit growth, despite their overall formidable economic performance since the beginning of their transition to market economies. Sirtaine S. Skamnelos I. (2007, p 31.) raises the question of whether the current credit growth is excessive or not. Arguments have been made, in their paper and in literature, in both directions. (Sirtaine S. Skamnelos I. ibid.)

Through the monitoring of changes in bank loans over the last decade, the results of research of Guo K and V. Stepanyan (2011) show that domestic and foreign funding contribute positively and symmetrically to credit growth. These results also show that stronger economic growth leads to higher credit growth and high inflation, while increasing nominal credit, is detrimental to real credit growth. Loose monetary conditions, either domestic or global, results and more credit, and the health of the banking sector also matters.

\section{Data analysis and methodologies}

The date used for this study are the official date published by the Central Bank of Bosnia and Herzegovina and Banking Agency of the FB\&H and the Banking Agency of the Republic of Srpska, from the period: Q1 2007 - Q2 2015. The research will also use the statistical package SPSS 16.0. The loan growth rate will be observed as a dependent variable. The independent variables are as follows:

GRNPL - The growth rate of non-performing loans;

GROC - The growth rate of operating costs;

RGDPG - Real GDP growth;

$\mathrm{CPI}$ - Consumer price index;

DGR - Deposit growth rate;

DIR - Deposit interest rate;

EURIBOR - Euro interbank offered rate; and

LIBOR - The London Interbank Offered Rate.

The regression model is an equation with a finite number of parameters and variables. Depending on whether a model comprised only one or more variables, there are simple and multiple linear regression models respectively. In addition to a dependent variable and one or more independent variables, each regression model contains a random variable. A simple linear regression model expresses a relationship between the two parameters as follows:

$Y_{i}=\alpha+\beta X_{i}+\varepsilon_{i} \quad i=1,2, \ldots \ldots n$, 
Alihodžić A., Plakalović N.: Determinants of Credit Growth to Nonfinancial companies..

where:

$Y$ - dependent variable,

$\alpha$ i $\beta$ - unknown parameters that need estimate, and

$\varepsilon_{i}-$ stochastic variable (error distances).

Unlike the simple regression model, the multiple-linear regression model is different in that it comprises two or more independent variables.

$Y_{i}=\alpha+\beta_{1} X_{i, 1}+\beta_{2} X_{i, 2}+\cdots+\beta_{i} X_{i, j}+\cdots+\beta_{k} X_{i, k}+\varepsilon_{i}$

$i=1,2, \ldots . n$.

Specifically, this model consists of independent variable $Y$, and $K$ independent variables, which are referred to as: $X_{-}(i, j)=1,2, \ldots \ldots, K$.

Table 1. Descriptive explanation of the variables in the model

\begin{tabular}{|c|c|c|}
\hline Variable & Symbol & Description \\
\hline Loan growth rate & LGR & $\begin{array}{l}\text { The annualized change in total loans from the } \\
\text { previous quarter, expressed as a percentage of total } \\
\text { loans at the end of the previous quarter. }\end{array}$ \\
\hline $\begin{array}{l}\text { Growth rate } \\
\text { nonperforming loans }\end{array}$ & GRNPL & $\begin{array}{l}\text { Banks nonperforming loans to total gross loans (in } \\
\%)\end{array}$ \\
\hline $\begin{array}{l}\text { The growth rate of } \\
\text { operating costs }\end{array}$ & GROC & Operating costs-to-total earning assets (in \%) \\
\hline Real GDP growth & RGDPG & Real GDP growth \\
\hline $\begin{array}{l}\text { Consumer Price } \\
\text { Index }\end{array}$ & $\mathrm{CPI}$ & Consumer Price Index \\
\hline Deposit growth rate & DGR & $\begin{array}{l}\text { The Deposit Growth Rate compares the quantity of } \\
\text { deposits held by a financial institution in a given } \\
\text { period to the quantity of deposits from an earlier } \\
\text { period. }\end{array}$ \\
\hline Deposit interest rate & DIR & $\begin{array}{l}\text { The relationship between interest expenses and } \\
\text { average interest-earning liabilities }\end{array}$ \\
\hline $\begin{array}{l}\text { Euro Interbank } \\
\text { Offered Rate }\end{array}$ & EURIBOR & $\begin{array}{l}\text { Euribor is short for euro interbank offered rate. The } \\
\text { Euribor rates are based on the average interest } \\
\text { rates at which a large panel of European banks } \\
\text { borrow funds from one another. }\end{array}$ \\
\hline $\begin{array}{l}\text { The London } \\
\text { Interbank Offered } \\
\text { Rates }\end{array}$ & LIBOR & $\begin{array}{l}\text { The London Interbank Offered Rate is the average } \\
\text { interest rate estimated by leading banks in London } \\
\text { that the average leading bank would be charged if } \\
\text { borrowing from other banks }\end{array}$ \\
\hline
\end{tabular}

This empirical study refers to the loan growth rate of the banking sector in B\&H for the period from Q1 2007 to Q2 2015. The data used for this study are the official data (statistical analysis) of the Central Bank of Bosnia and 
Alihodžić A., Plakalović N.: Determinants of Credit Growth to Nonfinancial companies..

Herzegovina and Banking Agency of the Federation of Bosnia and Herzegovina (FB\&H) and the Banking Agency of the Republic of Srpska.

This study used a multiple-linear regression model that assesses the nature and strength of the bond between a dependent variable, and $\mathrm{K}$ independent variables that are marked with $X_{-}(i, j)=1,2, \ldots \ldots, K$. Therefore, in this study, loan growth rate of the banking sector in B\&H (LGR) is used as dependent variable, and the following ones as independent variables: the growth rate non-performing loan (GRNPL), the growth rate of operating costs (GROC), real GDP growth (RGDPG), consumer price index (CPI), deposit growth rate (DGR), deposit interest rate (DIR), Eurointer bank offered rate (EURIBOR), and The London Inter bank offered rate (LIBOR).

The regression model in this study is presented as follows:

$$
\begin{aligned}
(L G R)=\alpha+\beta_{1} * & (G R N P L)+\beta_{2} *(G R O C) * \beta_{3} *(R G D P G)+\beta_{4} *(C P I)+\beta_{5} *(D G R) \\
& +\beta_{6} *(D I R)+\beta_{7} *(\text { EURIBOR })+\beta_{8} *(L I B O R)
\end{aligned}
$$

The representativeness of the model will examine calculation of the coefficient of correlation (r), the coefficient of determination $\left(R^{2}\right)$ and adjusted coefficient of determination $\left(\bar{R}^{2}\right)$. There is also an analysis of variance (ANOVA), which will test the significance of observed financial variables in the model, where the null hypothesis is the reason why the independent variables do not significantly affect the dependent:

$$
\begin{aligned}
& H_{0} \ldots \beta_{1}=0 \\
& H_{1} \ldots \beta_{1} \neq 0
\end{aligned}
$$

The table below illustrates the descriptive statistics of the example.

Table 2. Descriptive statistics of the observed banking performance for the period: Q1 $2007-$ Q2 2015

\begin{tabular}{lccc}
\hline $\begin{array}{c}\text { Dependent and independent } \\
\text { variables in the model }\end{array}$ & Means & Std. Deviation & $\mathrm{N}$ \\
\hline LGR & 1.529 & 2.608 & 34 \\
GRNPL & 9.176 & 4.764 & 34 \\
GROC & 0.441 & 0.504 & 34 \\
RGDPG & 6.150 & $698.365,44$ & 34 \\
CPI & 1.091 & 5.529 & 34 \\
DGR & 2.206 & 4.829 & 34 \\
DIR & 1.265 & 0.931 & 34 \\
EURIBOR & 1.647 & 2.385 & 34 \\
LIBOR & 1.294 & 1.586 & 34 \\
\hline
\end{tabular}

Source: Calculation made by the author (SPSS 16.0) 
Alihodžić A., Plakalović N.: Determinants of Credit Growth to Nonfinancial companies..

The growth in the real gross domestic product, as well as the deposit growth rate, showed their highest volatility with a standard deviation of $698.36 \%$ and 4.83\% for the period from Q1 2007 to Q2 2015 (Table 2). According to the date the Central Bank of B\&H , the realest GDP growth in the reporting period was recorded in $2007(6 \%)$, so that in 2009 the real GDP growth recorded a negative value of $2.7 \%$. In the period after 2009 , there was a tendency of further decline in GDP until 2013, as a result of weak economic activity and weak domestic and foreign demand. According to the date of the B\&H Agency for Statistics (B\&H AS) real GDP growth in the fourth quarter of 2014, compared to the same quarter of the previous year, amounted to the high 2.4\% (Central bank of Bosnia and Hercegovina, Bulletin, No. 1., 2015, P. 38). In the first quarter of 2007, growth in deposits of the corporate sector amounted to $19.82 \%$, and at the end of the second quarter there was a decline in deposits to $2.12 \%$. The main reason given fluctuations in the nonbanking sector deposits may be mentioned primarily weakened export potential and illiquidity of the economy.

\section{The research results}

Results obtained by regression analysis indicated that the coefficient of correlation is $r=0.89$, indicating that there is a strong correlation between the dependent variable, i.e. the loans growth rate - (LGR) and independent variables: the growth rate of non-performing loans (GRNPL), the growth rate of operating cost (GROC), real GDP growth (RGDPG), consumer price index (CPI), deposit growth rate (DGR), deposit interest rate (DIR), interest rate (EURIBOR), and interest rate (LIBOR).

The coefficient of determination is $R^{2}=79 \%$, and the adjusted coefficient of determination is $\bar{R}^{2}=0.73$. The fact shows that this model described $73 \%$ of the variations to the independent variables makes the model relatively representative. The significance test also indicates that there is a substantial influence of certain independent variables on the dependent variable. The testing the null hypothesis of significance obtained statistically significant data indicating that there is significant influence of certain independent variables at a significance level of $\alpha=5 \%$, and that the empirical $F$-ratio is (11.92) As for this study, the value of the empirical F-ratio (11.92) is greater than the theoretical value of F-ratio (2.34) for the 8-degree of freedom in the numerator and 25 in the denominator, then we come to the conclusion to reject the null hypothesis that the independent variables have a significant impact on the dependent variable. Durbin-Watson statistics shows high correlation with respect to the value above 2 . 
Alihodžić A., Plakalović N.: Determinants of Credit Growth to Nonfinancial companies..

Table 3. Regression analysis between the following parameters: GRL, GRNPL, GROE, RGDPG, CPI, DGR, DIR, EURIBOR, LIBOR in B\&H for the period Q1 2007 Q2 2015

\begin{tabular}{ll}
\hline Regression Statistics & \\
\hline Multiple R & 0.890 \\
R Square & 0.792 \\
Adjusted R Square & 0.726 \\
Std. Error of the Estimate & 1.365 \\
Durbin - Watson & 2.137 \\
\hline
\end{tabular}

Source: the calculation made by the author (SPSS 16.0)

Table 4. Analysis of variance between the following parameters: GRL, GRNPL, GROE, RGDPG, CPI, DGR, DIR, EURIBOR, LIBOR in B\&H for the period Q1 2007 Q2 2015

\begin{tabular}{lccccc}
\hline ANOVA & Df & SS & MS & F & Significance F \\
\hline Regression & 8 & 177.855 & 22.232 & 11.923 & 0.000 \\
Residual & 25 & 46.616 & 1.865 & - & - \\
Total & 33 & 224.471 & - & - & - \\
\hline
\end{tabular}

Based on the outputs as shown in the Table 4 (column where is Sig $=0.000$ ) we can also conclude that the null hypothesis is null, the meaning that the coefficient of determination for our regression model is different from zero. Comparing the standard error of the estimate (Table 3 - 1.365) with a standard deviation of the dependent variable (Table 2 - 2.61), it is evident that the standard error of the estimate is significantly lower than the standard deviation of the dependent variable, which helps in reducing errors in the assessment, i.e. predicting the dependent variable.

Table 5. The matrix of correlation coefficients between the parameters: LGR, GRNPL, GROE, RGDPG, CPI, DGR, DIR, EURIBOR, LIBOR in B\&H for the period: Q1 2007-Q2 2015

\begin{tabular}{cccccccccc}
\hline & LGR & GRNPL & GROC & RGDPG & CPI & DGR & DIR & EURIBOR & LIBOR \\
\hline LGR & 1.000 & -0.620 & -0.020 & 0.584 & 0.128 & 0.530 & -0.047 & 0.377 & 0.833 \\
GRNPL & -0.620 & 1.000 & -0.084 & 0.619 & -0.629 & -0.214 & -0.154 & -0.234 & -0.825 \\
GROC & -0.022 & -0.084 & 1.000 & 0.177 & 0.069 & -0.238 & 0.777 & 0.083 & 0.136 \\
RGDPG & 0.584 & 0.619 & 0.177 & 1.000 & 0.338 & -0.293 & 0.301 & -0.105 & -0.565 \\
CPI & 0.128 & -0.629 & 0.069 & -0.338 & 1.000 & -0.261 & 0.155 & -0.018 & 0.360 \\
DGR & 0.530 & -0.214 & -0.238 & -0.293 & 0.261 & 1.000 & -0.215 & 0.246 & 0.356 \\
DIR & -0.047 & -0.154 & 0.777 & 0.301 & 0.155 & -0.215 & 1.000 & 0.084 & 0.171 \\
EURIBOR & 0.377 & -0.234 & 0.083 & -0.105 & 0.018 & 0.246 & 0.084 & 1.000 & 0.469 \\
LIBOR & 0.833 & -0.825 & 0.136 & -0.565 & 0.360 & 0.356 & 0.171 & 0.469 & 1.000 \\
\hline
\end{tabular}

Source: Calculation by Author's (SPSS 16.0)

Industrija, Vol.44, No.2, 2016 
Alihodžić A., Plakalović N.: Determinants of Credit Growth to Nonfinancial companies..

The coefficient of correlation can take values from -1 to +1 . Thus, the resulting ratio shows the strength of the two observed parameters. A value of zero indicates that there is no correlation, while the value of 1.0 indicates the correlation between complete and connected, and the value of -1.0 indicates the correlation between complete and negative. The table above clearly shows that a small number of variables are slightly negatively correlated, and on the other hand, it shows that the small number of observed variables have a positive correlation. Given the case analysis of the influence of independent variables on the dependent variable, and the loans growth rate, it can be seen that the strongest positive correlation was observed between the loans growth rate and the interest rate LIBOR (0.833). As it is known that with an increase in interest rates tends to lead to reduced lending activity, in the above-shown in this table is present to reverse the trend in the movement, i.e. where did present the strongest positive relationships between LIBOR and credit growth rates (0.833). Given that as a reference interest rate in B\&H takes EURIBOR and LIBOR, which serve as a benchmark in determining the average interest rate on the market, trends in itself shows the inverse proportionality. In the period from the first quarter of 2007 to the second quarter of 2015, we have continued declining trend in interest rates EURIBOR and LIBOR; on the other hand, the average interest rate in B\&H does not follow the same trend, but tends to increase. The impact of interest rates on the European money market has the effect transmission mechanism through which departs from the Central Bank, which holds liquid assets to short-term basis in European banks with the highest credit ratings. This implies a relatively lower interest rate that accompanies a high credit rating of European banks working with the Central Bank. Considering that the CBB\&H holds reserves of domestic banks on accounts from foreign banks that interest rates on these funds are dictated by interest rates on the reserves and excess reserves as by the reserve requirement by the Central Bank is calculated to commercial banks. The second channel effects of interest rates from the European market is the term of deposits of domestic banks in the accounts of foreign banks, which in conditions of extremely low-interest rates is absolutely unprofitable for banks (Plakalovic, N. p 9). Also, between the loans growth rate and real GDP growth recorded a positive correlation (0.584). This is quite reasonable and logical, because with an increase in economic activity, this leads to an increase of banking assets, and consequently in increase in lending activity.

Observed, on the other hand, the strongest negative correlation was observed between the loans growth rate and growth rate of non-performing loans (0.620). This is quite reasonable and logical, because the banks by increasing non-performing loans in their portfolios slowing lending activity and creating a provision in case of default on credit debt. The movement of non-performing loans in the banking sector of Bosnia and Herzegovina for the period: Q1 2007 - Q2 2015 shows a tendency of the linear increase until 2013, and 
Alihodžić A., Plakalović N.: Determinants of Credit Growth to Nonfinancial companies..

relative in the study by Favara weak reduction to the second quarter of 2015. The high level of non-performing loans at several banks has led to a high share of non-performing loans at the level of the total banking sector. According to the results of stress tests for 2013, carried out regularly by the Central Bank of Bosnia and Herzegovina (CBB\&H), the increase in the loan portfolio is primarily influenced by slow economic activity. On the other hand, the increase in non-performing loans is followed as a consequence of increased interest rates (Central bank of Bosnia and Herzegovina, Financial Stability Report, 2013, pp. 42-43).

Table 6. Regression analysis coefficients between the following parameters: LGR, GRNPL, GROC, RGDPG, CPI, DGR, DIR, EURIBOR, LIBOR in B\&H for the period: Q1 2007-Q2 2015

\begin{tabular}{ccccccccc}
\hline Model & $\begin{array}{c}\text { Unstandardized } \\
\text { Coefficients } \\
\text { B }\end{array}$ & $\begin{array}{c}\text { Std. } \\
\text { Error }\end{array}$ & $\begin{array}{c}\text { Standardized } \\
\text { Coefficients } \\
\text { Beta }\end{array}$ & $\mathrm{t}$ & Sig & $\begin{array}{c}\text { Zero } \\
\text { order }\end{array}$ & $\begin{array}{c}\text { Correlatio } \\
\text { ns } \\
\text { Partial }\end{array}$ & Part \\
\hline (Constant) & 5.442 & 8.838 & - & 0.616 & 0.544 & - & - & - \\
GRNPL & 0.097 & 0.123 & -0.177 & 0.788 & 0.438 & -0.620 & 0.156 & 0.072 \\
GROC & 0.120 & 0.781 & -0.023 & 0.154 & 0.879 & -0.022 & 0.031 & 0.014 \\
RGDPG & 4.919 & 0.001 & 0.132 & 0.928 & 0.362 & 0.584 & 0.182 & 0.085 \\
CPI & 0.032 & 0.067 & 0.069 & 0.480 & 0.635 & 0.128 & 0.096 & 0.044 \\
DGR & 0.103 & 0.064 & 0.190 & 1.609 & 0.120 & 0.530 & 0.306 & 0.147 \\
DIR & 0.270 & 0.468 & -0.096 & -0.576 & 0.570 & -0.047 & -0.114 & -0.052 \\
EURIBOR & 0.066 & 0.120 & 0.061 & 0.552 & 0.586 & 0.377 & 0.110 & 0.050 \\
LIBOR & 1.485 & 0.336 & 0.903 & 4.422 & 0.001 & 0.833 & 0.662 & 0.403 \\
\hline
\end{tabular}

Source: The Calculation made by the Author (SPSS 16.0)

From the table above it is clear that the loans growth rate - the LGR has the strongest positive linear relationship to the LIBOR (0.903), following by deposit growth rate - DGR (0.190), then with the real GDP growth rate RGDPG (0.132), also with the consumer price - CPI (0.069) and EURIBOR (0.061). To its opposite, the weakest linear relationship was observed between the growth rate of non-performing loans - GRNPL $(-0.177)$, the deposit interest rate - DIR $(-0.096)$ and the growth rate of operating costs GROC (-0.023). The most important risk in the banking sector stands out credit risk. This is the risk of default. Despite the rapid expansion of innovation in the financial services sector at the turn of this century, the credit risk is an essential reason for the insolvency of banks, because in modern business conditions over $80 \%$ of the bank's balance sheet relating to this segment of banking risk management. In addition to these factors that affect the amount of credit risk should be taken into consideration and decrease the creditworthiness of the borrower, and increase the likelihood that the bank's clients come in no position to fulfil their obligations (Đukic, Đ. 2011, p 22). The high level of non-performing loans at several banks has led to a high share of 
Alihodžić A., Plakalović N.: Determinants of Credit Growth to Nonfinancial companies..

non-performing loans at the level of the entire banking sector. At the end of 2007 the share of non-performing loans to total loans amounted to only $3 \%$, whereas at the end of the second quarter of 2015 the share of non-performing loans of total loans amounted to $14.1 \%$. The largest share of non-performing loans in the portfolio of total loans was recorded in 2013 , and as of $15.1 \%$.

According to the results of the stress tests for 2013 carried out regularly by the Central Bank of B\&H to increase the poor quality of the portfolio is primarily influenced by slow economic activity. While, the increase in nonperforming loans is followed as a consequence of increased interest rates (Financial Stability Report, 2013, CBB\&H, p 42-43). In the period from the first quarter of 2007 to the second quarter of 2015, there was an average increase in operating costs by approximately $5.18 \%$ on a quarterly basis, which indirectly reflected the burden of banks assets in $\mathrm{B} \& \mathrm{H}$, and in this regard the price increase lending and consequently reduced credit activity. From the above given table, the negative causality between interest rates on deposits and credit growth (-0.09), is also present, which is quite logical, because with the increase in deposit interest rates banks have adjusted their lending rates in order to maintain the net interest margin.

\section{Conclusions}

This paper analyses the determinants of the loans growth rate of the banking sector in B\&H in the period between Q1 2007 - Q2 2015, using multiple linear regression models. In the quantitative analysis, it is assumed that the loans growth rate of the banking sector in B\&H (LGR) is used as dependent variable, and the following ones as independent variables: the growth rate of non-performing loans, the growth rate of operating costs, real GDP growth, consumer price index, deposit growth rate, deposit interest rate, interest rate (EURIBOR), and interest rate (LIBOR). The null hypothesis was rejected because it was not shown that the independent variables affect the dependent variable.

In the study, we found that there is a very high degree of correlation between GDP growth, which we viewed as an independent variable and rate of credit growth. Although the highest degree of correlation is present between credit growth and rising LIBOR and EURIBOR there is no connection between these rates and the movement of interest rates in $\mathrm{B} \& \mathrm{H}$. The reason for this is the high level of credit risk and monopolistic banks as almost the exclusive source of external funds for financing company in B\&H. The movement of GDP has also a high correlation. Even greater correlation is observed between the GDP and the non-performing loans which are quite expected. A significant slowdown in economic growth and long-term recessionary trends in the 
Alihodžić A., Plakalović N.: Determinants of Credit Growth to Nonfinancial companies..

economy of Bosnia and Herzegovina have influenced that many companies get into trouble and cannot properly service their debts and thus affect the growth of NPLs. Bank operating expenses show a high degree of correlation with the movements of interest rates on bank deposits. Future research on this topic can be expanded depending on the availability of the database, so that the use of more appropriate explanatory variables for a longer period can get a better analysis.

\section{References}

Duenwald, C., Gueorguiev, N., \& Schaechter, A. (2005). TooMuch of Good Thing? Credit Booms in Transition Economies: The Cases of Bulgaria, Romania, and Ukraine. IMF Working Paper, WP/128.

Đukic, Đ. (2011). Risk management and capital in banks, Publishing Centre of Faculty of Economics in Belgrade.

Espinoza, R., \& Prasad, A. (2010). Nonperforming Loans in the GCC Banking System and their Macroeconomic Effects. IMF Working Paper, WP/224.

Favara, G. (2003). An Empirical Reassessment of the Relationship Between Finance and Growth. IMF Working Paper,WP/123.

Garcia-Escribano, M., \& Han, F. (2015). Credit Expansion in Emerging Markets: Propeller of Growth?. IMF Working Paper,WP/212.

Guo, K., \& Stepanyan, V. (2011). Determinants of Bank Credit in Emerging Market Economies. IMF Working Paper, WP/51.

-International Monetary Fond. (2006). Spain: Financial Sector Assessment ProgramTechnical Note-Stress testing Methodology and Results. IMF Country Report, 6(216),

Levine, R., Loayza, N., \& Beck, T. (2000). Financial Intermediation and Growth: Causality and Causes. Journal of Monetary Economics, 46, 31-77.

Magud, N., Reinhart, C., \& Vesperoni, E. (2012). Capital Inflows, Exchange Rate Flexibility, and Credit Booms. IMF Working Paper, WP/41.

Sirtaine, S., \& Skamnelos, I. (2007). Credit Growth in Emerging Europe, A Cause for Stability Concerns?. The World Bank, Policy Research Working Paper, WPS4281.

-The Central Bank of Bosnia and Herzegovina. (2013). Financial Stability Report. Retrieved from http://www.cbbih.ba

-The Central Bank of Bosnia and Herzegovina. (2014). Financial Stability Report. Retrieved from http://www.cbbih.ba 